\title{
Managing Population Sex Ratios in Conservation Practice: How and Why?
}

\author{
Claus Wedekind \\ Department of Ecology and Evolution, Biophore, \\ University of Lausanne, Lausanne, \\ Switzerland
}

\section{Introduction}

Small or declining populations are at increased risk of extinction because of stochasticity and Allee effects (Lande 1998, Courchamp et al. 1999, Stephens and Sutherland 1999, Bourbeau-Lemieux et al. 2011), and several genetic problems that include reduction in genetic variability, an accumulation of deleterious mutations due to random drift, and increased rates of inbreeding depression (Frankham et al. 2002, Hedrick 2005, Allendorf and Luikard 2007). Genetic problems are likely to reduce the average viability of individuals from generation to generation, and they reduce evolutionary potential and therefore the long-term survival expectancies, especially of small populations (Frankham et al. 2002, Hedrick 2005, Allendorf and Luikard 2007). However, genetic problems are only indirectly linked to the census size $\left(\mathrm{N}_{\mathrm{c}}\right)$. Instead, they are directly dependent on the genetically effective population size $\left(\mathrm{N}_{\mathrm{e}}\right)$ that is defined as the size of an ideal model population that looses genetic variability at the same rate as the observed population. Usually, $N_{e}$ is significantly smaller than $\mathrm{N}_{c}$ because of variance in individual reproductive success, deviations from a 1:1 operational sex ratio, and other reasons. Risks of extinction are therefore increased if population sex ratios deviate from 1:1.

We typically expect 1:1 sex ratios in natural populations because of strong frequencydepended selection on the production of sons and daughters (Fisher 1930). However, population sex ratios can be biased by non-random harvest as a consequence of, for example, sex differences in behavior, size, or morphology, or simply as a consequence of hunter preferences (Bunnefeld et al. 2009, Tryjanowski et al. 2009, Marealle et al. 2010). Sex ratios can also be influenced by environmental changes such as, for example, different kinds of chemical pollution or changes in the temperature regime that may cause sex-specific mortality or growth. Environmental changes can even directly influence the production of males and females in species with environmental sex determination (Janzen 1994, Kamel and Mrosovsky 2006), or in species where the genetically determined sex can be reversed during a critical period in life. Such environmental sex reversal has been observed in several fish and amphibians (Wallace et al. 1999, Devlin and Nagahama 2002, Baroiller et al. 2009, Stelkens and Wedekind 2010), may potentially be more likely under many of the rapid environmental changes we are currently observing, but may well have happened frequently even before anthropogenic effects on the environment became ubiquitous (Perrin 2009). 
Lastly, parents (especially mothers) of many species are able to manipulate family sex ratio, as will be explained below. There are examples where the combined effects of such parental life-history decisions have lead to distorted population sex ratios (Robertson et al. 2006).

We may be able to manipulate and hence manage population sex ratios to benefit biodiversity if we understand how they are influenced under natural and artificial conditions. We may either aim for maximizing the evolutionary potential and hence the long-term perspectives of a given population, or wish to control the growth of problem populations (e.g. of exotic species). Among the various tools that have been proposed for manipulating sex ratios are the 'sterile male' strategy, the 'Trojan Y chromosome', and recombinant constructs that lead to gender distortion (Gutierrez and Teem 2006, Cotton and Wedekind 2007a, Bax and Thresher 2009). Alternatively, maternal life-history strategies can sometimes be manipulated in order to affect family sex ratios, and some species even allow for sex ratio manipulation by simple manipulations of the micro-ecological conditions during critical stages in ontogeny.

In the following I summarize the current knowledge about how population sex ratios develop, and how they can change due to, for example, changed temperature regimes, different kinds of chemical pollution, or other environmental changes. I will then outline the various tools that could be used to manipulate sex ratios and give some examples from the literature. I will discuss the potential risks and benefits of such manipulations, and I will list a number of key questions that still need to be answered in order to optimize the management of population sex ratios.

\section{What affects family sex ratios?}

When discussing family sex ratios, it is useful to distinguish between the different possible explanatory levels, especially between proximate and ultimate explanations (Tinbergen 1963). Proximate (mechanistic) explanations of family sex ratio deal with questions about the genetic, physiological, and molecular aspects of, for example, sex determination. Ultimate (evolutionary) explanations concentrate on the adaptive value of a given family sex ratio, especially on the impact of a parent's fitness, without necessarily explaining the proximate aspects. Obviously, proximate arguments often set constraints to what parents may be able to achieve in order to maximize fitness.

If sex determination is purely environmental, as in most reptiles, sex is not determined at conception but later during a specific window of time during embryonic or larval development. The window is often called "the thermosensitive period" because incubation temperature is often the most important sex-determining factor in these species (Valenzuela and Lance 2004). Purely environmental sex determination has been assumed to be quite common also in fish. However, Ospina-Alvarez and Piferrer (2008) argued that among the many species for which sex-determining chromosome have not (yet) been identified, species should only be considered as having a purely environmental sex determination if sex is determined by environmental conditions that can be considered as normal and within the range usually experienced under natural conditions. Applying this condition leaves only few species of four teleost orders with purely environmental sex determination. Among them, three different types of reaction norms dominate: (i) decreased or (ii) increased 
frequency of males with increasing temperature, or (iii) high frequency of males at extreme (high or low) temperatures (Devlin and Nagahama 2002, Ospina-Alvarez and Piferrer 2008, Baroiller et al. 2009).

In species with environmental sex determination, the within-population variance in family sex ratio can be very high due to variance in the micro-ecological conditions that affect eggs or larvae. Moreover, regional changes in the environment can easily lead to skewed population sex ratios in some years (Janzen 1994, Kamel and Mrosovsky 2006). Rapid and consistent environmental changes could then have dramatic consequences on population growth especially in small population of limited genetic variability, or in fragmented populations with limited gene flow. However, correlated changes in nesting or spawning time (Janzen et al. 2006, Wedekind and Küng 2010) or other changes in behavior and life history could potentially mitigate some of these negative effects of environmental changes. Moreover, some species seem to have the potential for (rapid) evolution in response to changed environments (Conover and Van Voorhees 1990, Conover et al. 1992, Magerhans et al. 2009).

In many fish and amphibians, sex determination is genetic but reversible by environmental factors during a sensitive period that is typically very early in life. Environmental sex reversal can be induced by various factors, including temperature changes or exposure to hormone active substances (Wallace et al. 1999, Devlin and Nagahama 2002, Baroiller et al. 2009). It is nowadays even used in fish farming to produce more profitable one-sex cultures (Pandian and Sheela 1995, Piferrer 2001, Cnaani and Levavi-Sivan 2009). Distorted sex ratios in the wild could potentially be caused by environmental sex reversal (Olsen et al. 2006, Brykov et al. 2008, Alho et al. 2010). Sex hormones, hormone-active substances, and endocrine disrupting chemicals are frequently released into natural watercourses, for example, in effluents from domestic and industrial sources (Larsson et al. 2000, Parks et al. 2001, Jobling and Tyler 2003). Fish exposed to such chemicals often display reduced reproductive performance (Vos et al. 2000), and exposure to such chemicals could well be responsible for gonadal malformations if, for example, sex reversal was incomplete leading to individuals that display gonadal characteristics of both sexes. A sudden increase in the prevalence of intersex or of other gonadal malformations is indeed frequently observed in natural populations (Harries et al. 1997, Bernet et al. 2004, Penáz et al. 2005, Jobling et al. 2006, Bernet et al. 2008, Bittner et al. 2009). Other possible consequences of exposure to hormones or hormone-active substances may include reductions in gonadal growth, a delayed onset of sexual maturity, inhibition of spermatogenesis, lower egg production, or reduced egg quality (Sumpter and Jobling 1995) (Vos et al. 2000). However, sex ratios in the wild can be skewed for many reasons (Palmer 2000), and environmentally induced sex reversal is often difficult to prove (Nagler et al. 2001, Chowen and Nagler 2004, 2005, Williamson et al. 2008). The prevalence and significance of environmental sex reversal in the wild is therefore still unclear (Wedekind 2010). So far, the consequences of environmentally induced sex reversal have only been analyzed in theoretical studies (Kanaiwa and Harada 2002, Hurley et al. 2004, Cotton and Wedekind 2009). These studies suggest that environmentally induced sex reversal can change population growth and population sex ratios in ways that may sometimes be counter-intuitive. A moderate rate of feminization, i.e. of an environmentally-induced development of the female phenotype despite male sex 
chromosomes, could sometimes be beneficial for population growth, especially in the absence of strong viability effects of the sex reversal. However, most possible outcomes of environmental sex reversal are negative with regards to population growth or the persistence of sex chromosomes. For example, strong environmental feminization over several generations leads to high rates of $Y Y$ individuals and can eventually lead to the extinction of $X$ chromosomes (Cotton and Wedekind 2009). Analogously, continuous environmental masculinization increases the rate of $X X$ individuals and can drive the $Y$ chromosome to extinction (Cotton and Wedekind 2009). If sex chromosomes are lost, i.e. if populations loose their genetic sex determination in response to environmental factors that induce sex reversal, the affected population may quickly go extinct if the environmental forces that cause sex reversal cease.

The frequency-dependent selection on the production of sons and daughters is a consequence of the fact that every sexually produced individual usually has exactly one father and one mother. This explains why 1:1 sex ratios are so common. Such equal sex ratios are easier to achieve if sex determination in purely genetic as compared to if sex determination is environmentally biased. Sex determination is purely genetic in all mammals and birds and in many species of other taxa. However, even in these taxa, equal primary sex ratios are a rule with exceptions, and parents of many species are often able to somehow manipulate family sex ratio. The physiology of such manipulations is often not clear yet, but there are good reasons why skewed family sex ratio may offer fitness benefits. If, for example, one sex is more costly to produce and raise than the other one, parents who are able to weight the relative investment into sons and daughters according to the expected fitness return would achieve higher fitness than parents who would not be able to do so (Charnov 1982).

The relative value of sons and daughters may differ for different parents. This is especially so if the expected fitness return of one type of offspring is more dependent on resources received from the parents than the expected fitness return of the other type of offspring. This is a typical outcome in polygamous species where, for example, few dominant males receive an increased reproductive success at the expense of outcompeted males. In such cases, parents that are in good condition or experience favorable conditions would increase their fitness by producing more offspring of the sex with the greater requirements, while parents in suboptimal condition should rather "play safe" and produce the other sex that promises a lower variance in reproductive success (Trivers and Willard 1973). This hypothesis received much empirical support in a variety of taxa (Gomendio et al. 1990, Cassinello and Gomendio 1996, Bradbury and Blakey 1998).

If family sex ratio can be adjusted in response to parental condition, it seems reasonable to assume that mate attractiveness could influence overall parental investment and maybe even family sex ratio. Indeed, females of various taxa have been observed to produce relatively more sons if mated with an attractive male rather than if mated with an less attractive male (Burley 1982, Ellegren et al. 1996), possibly because sons of attractive males may generally be more likely to achieve high reproductive success than sons of less attractive males. However, the effect could not always be observed (Westerdahl et al. 1997, Saino et al. 1999). Moreover, skewed family sex ratios do not necessarily reflect adaptive parental strategies (Krackow 1995). 


\section{Managing population sex ratio}

\subsection{Why?}

There are several good reasons why conservation managers could potentially profit from manipulating population sex ratios (Table 1). First, sex ratios of a small and endangered population are sometimes significantly skewed towards too many females or too many males. Such non-equal sex ratios increase the negative effects of Allee effects and demographic stochasticity, sometimes leading to extinction. For example, the last six individuals of the Dusky Seaside Sparrow (Ammodramus maritimus nigrescens) that remained and were kept in a captive breeding program turned out to be all male. This subspecies is now believed to be extinct (en.wikipedia.org from Feb $6^{\text {th }}$ 2012). Non-equal sex ratios also reduce the genetically effective population size because $\mathrm{N}_{e}=4 \mathrm{~N}_{\mathrm{m}} \mathrm{N}_{\mathrm{f}} /\left(\mathrm{N}_{\mathrm{m}}+\mathrm{N}_{\mathrm{f}}\right)$, with $\mathrm{N}_{\mathrm{m}}$ and $\mathrm{N}_{\mathrm{f}}$ being the number of mature males and females, respectively (Hartl 1988). In harem-based mating systems, $\mathrm{N}_{e}$ is even better described as $\mathrm{N}_{\mathrm{e}}=4 \mathrm{~N}_{\mathrm{m}} \mathrm{N}_{\mathrm{f}} /\left(2 \mathrm{~N}_{\mathrm{m}}+\mathrm{N}_{\mathrm{f}}\right)$ (Nomura 2002). Therefore, populations with non-equal sex ratios are expected to lose more genetic variability (i.e. evolutionary potential) and suffer more from the negative consequences of inbreeding than populations with equal sex ratios. Moreover, in species where population growth is limited by the availability of oocytes, male-biased sex ratios directly reduce population growth. For example, the remaining population of the critically endangered kakapo (Strigops habroptilus) of New Zealand has been found to be significantly male biased, probably as an undesirable side effect of supplementary feeding (Tella 2001, Clout et al. 2002). Because this parrot is also a species for which population growth is severely limited by egg production, manipulating family sex ratios towards more daughters (by methods that are outlined below) quickly became one of the priorities of the conservation management of this species (Robertson et al. 2006).

Second, if population sex ratios are not significantly skewed, but population size is small and population growth is limited by the availability of oocytes, manipulating sex ratio towards a female bias could sometimes be desirable, especially if very small or rapidly declining populations call for emergency actions. For example, captive breeding programs are typically not only meant as a refuge in response to a temporary ecological crisis, but they often aim at releasing additional individuals into the wild to support small or declining populations and to help preventing further losses of genetic diversity (Young and Clarke 2000). Such captive breeding programs sometimes even include the use of assisted reproductive technologies (Gibbons et al. 1995, Dobson and Lyles 2000, Lanza et al. 2000). There are a number of potential risks that need to be considered in such programs. These risks include, among others, a general increase in the variance in reproductive success and hence a reduction in overall $\mathrm{N}_{\mathrm{e}}$ (Ryman and Laikre 1991), potential negative effects of circumventing natural mate preferences (Grahn et al. 1998, Wedekind et al. 2001, Wedekind 2002b, Jacob et al. 2010), and artificial selection favoring certain life-history characteristics (Heath et al. 2003, Wedekind et al. 2007). However, if we can assume that offspring have an enhanced survival in captivity and that the subsequent release of captive bred individuals into the wild has a positive effect of the long-term survival of the population, artificially changing family sex ratios towards a female bias could sometimes even further increase population growth rate. Such manipulations may be feasible within a captive breeding program, for example by manipulating female reproductive strategies, or directly within the 


\begin{tabular}{|c|c|c|c|c|c|}
\hline Observation & $\begin{array}{c}\text { Aim of } \\
\text { intervention }\end{array}$ & $\begin{array}{l}\text { Main reasons for } \\
\text { intervention }{ }^{* *}\end{array}$ & $\begin{array}{l}\text { Potential intervention } \\
\text { technique }\end{array}$ & $\begin{array}{l}\text { Immediate effect of the } \\
\text { intervention }\end{array}$ & $\begin{array}{r}\text { Typical taxa for } w 1 \\
\text { intervention may } 1 \\
\text { promising } \\
\end{array}$ \\
\hline \multirow[t]{2}{*}{$\begin{array}{l}\text { Biased sex ratio in } \\
\text { small population, } \\
\text { not caused by ESR* }\end{array}$} & $\begin{array}{l}\text { Remove sex ratio } \\
\text { bias }\end{array}$ & $1,2,3,4$ & $\begin{array}{l}\text { Manipulate parental } \\
\text { strategies }\end{array}$ & $\begin{array}{l}\text { Changes sex ratio of next } \\
\text { generation }\end{array}$ & $\begin{array}{l}\text { Polygamous species, or } \\
\text { monogamous species W } \\
\text { rates of extra-pair fertili }\end{array}$ \\
\hline & & & $\begin{array}{l}\text { Manipulate environment } \\
\text { during embryogenesis or } \\
\text { early larval stages }\end{array}$ & $\begin{array}{l}\text { Changes sex ratio of next } \\
\text { generation }\end{array}$ & $\begin{array}{l}\text { Species with environme } \\
\text { determination (e.g. turt } \\
\text { crocodiles, some fishes) }\end{array}$ \\
\hline \multirow[t]{3}{*}{$\begin{array}{l}\text { The growth of a } \\
\text { small population is } \\
\text { limited by the } \\
\text { availability of } \\
\text { oocytes }\end{array}$} & $\begin{array}{l}\text { Increase } \\
\text { population } \\
\text { growth rate }\end{array}$ & 1 & $\begin{array}{l}\text { Manipulate parental } \\
\text { strategies }\end{array}$ & $\begin{array}{l}\text { Changes family sex ratio in } \\
\text { order to create a female excess }\end{array}$ & $\begin{array}{l}\text { Polygamous species, or } \\
\text { monogamous species } \mathrm{W} \\
\text { rates of extra-pair fertili }\end{array}$ \\
\hline & & & $\begin{array}{l}\text { Manipulate environment } \\
\text { during embryogenesis or } \\
\text { early larval stages }\end{array}$ & $\begin{array}{l}\text { Changes sex ratio of next } \\
\text { generation to create a female } \\
\text { excess }\end{array}$ & $\begin{array}{l}\text { Species with environme } \\
\text { determination }\end{array}$ \\
\hline & & & $\begin{array}{l}\text { Introduction of Trojan sex } \\
\text { chromosome carriers }\end{array}$ & $\begin{array}{l}\text { Daughter-biased family sex } \\
\text { ratio in introduced } \\
\text { individuals }\end{array}$ & $\begin{array}{l}\text { Fishes and amphibians } \\
\text { ZZ/ZW sex determinat } \\
\text { ESR, and functional W- } \\
\text { chromosome }\end{array}$ \\
\hline $\begin{array}{l}\text { Biased sex ratio } \\
\text { caused by ESR }\end{array}$ & $\begin{array}{l}\text { Avoid short-term } \\
\text { and long-term } \\
\text { consequences of } \\
\text { ESR; increase } \\
\text { population growth }\end{array}$ & $1,2,3,4,5$ & $\begin{array}{l}\text { Identify and control driver } \\
\text { of ESR }\end{array}$ & $\begin{array}{l}\text { Genotype-phenotype } \\
\text { mismatch reduced; strong } \\
\text { immediate effects on } \\
\text { population size and sex ratio } \\
\text { possible (caution : continuous } \\
\text { ESR could lead to extinction } \\
\text { of one of the sex } \\
\text { chromosomes) }\end{array}$ & Many fishes and amph \\
\hline \multirow[t]{3}{*}{$\begin{array}{l}\text { Damaging effects of } \\
\text { invasive species }\end{array}$} & $\begin{array}{l}\text { Control or reduce } \\
\text { population } \\
\text { growth rates }\end{array}$ & 6 & $\begin{array}{l}\text { Introduction of 'Trojan Y } \\
\text { chromosomes' }\end{array}$ & $\begin{array}{l}\text { Male-biased family sex ratio } \\
\text { in introduced individuals }\end{array}$ & $\begin{array}{l}\text { Many fishes and amphi } \\
X X / X Y \text { sex determining } \\
\text { and functional } Y \text { chrom }\end{array}$ \\
\hline & & & $\begin{array}{l}\text { Introduction of sterile } \\
\text { males }\end{array}$ & $\begin{array}{l}\text { Immediate male bias, } \\
\text { increased male-male } \\
\text { competition, increased } \\
\text { number of non-fertilized eggs }\end{array}$ & Many species \\
\hline & & & $\begin{array}{l}\text { Introduction of the } \\
\text { recombinants } \\
\text { "daughterless" }\end{array}$ & $\begin{array}{l}\text { Male-biased family sex ratio } \\
\text { in introduced individuals }\end{array}$ & Some fishes \\
\hline
\end{tabular}

* Environmentally-induced sex reversal, i.e. mismatch between gender genotype and phenotype

** 1. Typical problems of small populations, i.e. increased risk of extinction because of demographic and effects, or various genetic problems

2. Increased two-sex demographic stochasticity (i.e. increased risk of loosing one sex)

3. Reduced $\mathrm{N}_{\mathrm{e}} / \mathrm{N}_{\mathrm{c}}$ ratio (i.e. increased genetic drift, reduction of overall heterozygosity, inbreeding depression)

4. Increased risk of losing cultural traits, especially if the sex ratio bias or the low population size is untypical

5. Increased risk of extinction of a sex chromosome

6. Various possible negative effects of an invasion, including a reducing biodiversity, altering ecosystem pr exotics acting as vectors of new diseases, etc. 
wild population, for example by releasing individuals that are more likely to produce daughters than sons (Cotton and Wedekind 2007b) (see below). It is important to note that such a sex-ratio manipulation has the immediate effect of reducing the $\mathrm{N}_{e}$ to $\mathrm{N}_{c}$ ratio (because $\mathrm{Ne}=4 \mathrm{~N}_{\mathrm{m}} \mathrm{N}_{\mathrm{f}} /\left(\mathrm{N}_{\mathrm{m}}+\mathrm{N}_{\mathrm{f}}\right)$ ), i.e. it increases the genetic bottleneck that the small population is going through. This increased bottleneck immediately increases demographic stochasticity and leads to a greater loss of genetic variance, higher inbreeding rates, and higher rates of genetic drift and hence of fixation of deleterious mutations. However, if the sex ratio manipulation is carefully applied, these immediate negative effects of the treatment can be outweighed by the increased reproduction rates and the accelerated population growth (Wedekind 2002a, Lenz et al. 2007, Cotton and Wedekind 2009).

Third, invasions by exotic species, for example after a planned or accidental release of a nonnative species, are a major threat to biodiversity in most regions of the world (Myers et al. 2000). Various methods have been proposed to deal with this threat, but some of these methods have frequently created further problems, e.g. the introduction of secondary controlling species (Louda and Stiling 2004). Biasing the sex ratio in such problem populations towards more males could be a largely reversible method that may not only reduce population growth but could even reduce average female fitness. Male harassment of females over mating could by itself accelerate population decline (Rankin and Kokko 2007). At very low population sizes, induced male biases could even enhance Allee effects (Stephens and Sutherland 1999). Sex ratio manipulation may hence be an attractive option in fighting or controlling exotic species.

Family sex ratio manipulation is possible in many taxa. The degree of the invasiveness of the manipulation spans from manipulating environmental conditions during embryo and larval development or manipulating female perception of certain environmental key factors to, for example, sperm sexing prior to assisted reproductive technology in captive breeding programs (Gibbons et al. 1995, Dobson and Lyles 2000, Lanza et al. 2000). With regard to the latter, some methods of micromanipulation and some in vitro culture conditions have been discussed as potentially having an effect on embryo sex ratio in mice and cattle (King et al. 1992, Gutierrez et al. 1995). It therefore seems possible that sex ratios could be manipulated if assisted reproductive technology is used to propagate a species. However, in the following discussion of sex ratio manipulation, I will concentrate on methods that are arguably less invasive and comparatively less expensive.

\subsection{Manipulating the rearing environment or maternal decisions}

Obviously, if sex determination is purely environmental, a simple manipulation of the environment that embryos, larvae, or juveniles experience during the critical window in time in which sex is determined can be sufficient. If this critical time is during egg development, as for example in most if not all turtles, eggs could be collected and incubated at temperatures that result in the desired family sex ratio. Alternatively, the conditions at the egg laying site could be artificially changed (Girondot et al. 1998). Analogous manipulations have been suggested from some amphibians (Solari 1994).

Manipulating family sex ratio is less straightforward in species with genetic sex determination. However, the frequent observation that females are somehow able to manipulate family sex ratio (or the sex of their one offspring) in response to ecological or 
social characteristics of the rearing environment may provide a number of options. If, for example, females adjust their family sex ratio in response to a perceived skew in the population sex ratio, skewed sex ratios could potentially be simulated in captive populations, for example by removing and housing members of one sex separately. Alternatively, the sensory stimuli that females use to perceive their social environment could be manipulated, for example by exposing the female to urine of different individuals in order to simulate a skewed population sex ratio (Perret 1996).

The Trivers-Willard hypothesis (Trivers and Willard 1973) predicts that in polygynous species, females in good conditions are more likely to have sons than daughters (see above). Such parental decisions could potentially be manipulated by manipulating the females' condition, for example by a changed feeding regime. The kakapo may be an example here. Supplementary feeding of the few remaining individuals of that species may have led to malebiased sex ratios because females in good conditions turned out to be more likely to have sons than daughters (Tella 2001, Clout et al. 2002). At one point in time, about $70 \%$ of all recorded offspring of this species were sons. Robertson et al. (2006) found that the male bias was significantly reduced when female condition was altered. Lenz et al. (2007) used this line of thought to work out the likely genetic and demographic consequences of analogous management actions in an existing captive breeding program for a Spanish population of the lesser kestrel (Falco naumanni), another polygynous bird that shows a correlation between family sex ratio and female condition: more daughters are born by mothers of average conditions, while more son are born by mothers of good condition (Aparicio and Cordero 2001). The authors found that a sex-ratio management within the range that seems possible would significantly increase the efficiency of an existing captive breeding program.

If females adjust their investment into sons and daughters according to male characteristics, it may be possible to exploit the rules that females use to determine the attractiveness of a male relative to all potential mates. Such decision rules are not likely to be entirely genetically fixed but may be rather flexible (Real 1991). Mate choice decisions can be the outcome of simple cost/benefit analyses (Milinski and Bakker 1992), and the perception of the attractiveness of a given male is expected to depend on female experience and hence on a sampling template given by the population. Such a sampling template could be manipulated in order to increase or decrease the perceived attractiveness of a given male. If, for example, the size or the color of a secondary sexual ornament determines sexual attractiveness, exposing the female to several (real or dummy) individuals with very weak sexual ornaments may make a male with medium-sized or medium-colored ornament more attractive. Analogously, exposing the female to several individuals with strong sexual ornaments may make the male with a medium-sized or a medium-colored ornament less attractive. Alternatively, many secondary sexual ornaments could be directly manipulated. Structural ornaments could be artificially elongated, colors could be enhanced painting the ornament, or the male could be presented under light conditions that accentuate the colors in question.

\section{3 'Trojan Y chromosomes' and genetic constructs that distort sex ratios}

Conservation practice sometimes includes managing potential problem populations (Kolar and Lodge 2002, Hanfling et al. 2011, Poulin et al. 2011). The 'sterile male' strategy is one of the various techniques that has been proposed. The idea is that large numbers of sterile males are produced and released into the wild in order to outcompete wild males for 
mating. So far, the application of this idea has largely concentrated on disease-transmitting insects (Thailayil et al. 2011). However, if females mate with only few males each, and the mating frequency of introduced sterile males is not significantly smaller than the mating frequency of wild males, the 'sterile male' strategy could potentially be applied more widely and also in the context of exotic species that need to be controlled. And even if the idea behind this technique is not primarily based on changing population sex ratio in order to manipulate population growth, it should nevertheless be discussed in the present context. Obviously, releasing large numbers of sterile males leads to a male-biased sex ratio that may, by itself, increase intra-individual competition and lead to a reduction of average female fitness not only because of the increased rate of non-fertilized eggs but also because of the likely negative effects of male-biased sex ratios in some sort of species (Rankin and Kokko 2007). Further recombination methods that have been discussed as possible pest control include sex-specific lethality constructs (Schliekelman and Gould 2000, Schliekelman et al. 2005). The effectiveness of the release of such constructs can be greatly enhanced by complementary management options such as selective harvest of males or females (Bax and Thresher 2009). However, the recombinant approach could lead to undesirable results if, for example, the gene construct jumps to other species (Kapuscinski et al. 2007).

Species with predominantly genetic but environmentally reversible sex determination (i.e. many fish and amphibians) offer another approach, the so-called 'Trojan Y chromosomes' strategy ('Trojan' genetic elements were originally defined as elements that have the potential of driving local populations to extinction (Muir and Howard 2004)). The necessary prerequisites are that (i) the species in question displays male heterogamety (i.e. $X X=$ female and $X Y=$ male), and that (ii) the $Y$-chromosome should not be significantly decayed as it usually is, for example, in most mammals because of the suppressed recombination between the sex chromosomes (Bull 1983, Rice et al. 2008) and the thereby resulting accumulation of deleterious mutations on the Y-chromosome (Muller 1932, Felsenstein 1974). Interestingly, in fish and amphibians with genetic but environmentally reversible sex determination, sex chromosomes are typically not heteromorphic, and the functionality of $Y$ chromosomes seems mostly unrestricted. This for itself leads to a number of interesting evolutionary questions (Perrin 2009), but what is probably most interesting in the present context is the fact that $Y Y$ individuals are therefore often viable. Such $Y Y$ individuals can be produced by mating feminized $X Y$ individuals with wild-type $X Y$ males. $Y Y$ individuals would normally be males who can only produce $X Y$ sons if mated with wild-type $X X$ females. Sex-reversed $Y Y$ individuals (i.e. females without $X$ chromosomes) would also be expected to have only sons if mated with a wild-type XY male. Moreover, half of these sons would have the YY genotype and could hence only have sons themselves. Gutierrez and Teem (2006) modeled the repeated introduction of $Y Y$ females as potential tool in conservation management. They found that such introduction of 'Trojan Y chromosomes' can potentially be used to control the growth of problem populations. Critical variables in these scenarios are the relative viability of carriers of these 'Trojan Y chromosomes' and their attractiveness in mate choice, i.e. their mating success relative to the wild-type females and males (Cotton and Wedekind 2009).

Some species that display environmentally reversible sex determination have a sex determination mechanism that is based on female heterogamety (i.e. $\mathrm{ZZ}=$ male and $\mathrm{ZW}=$ female). Introducing sex-reversed WW individuals would then lead to an increased population growth, especially if the induced sex change had no significant effect on viability 
and mating success (Cotton and Wedekind 2007b). Boosting population growth with 'Trojan sex chromosomes' may currently have the highest potential in the conservation of amphibians. Many amphibian display female heterogamety (Hillis and Green 1990), are susceptible to environmental influences during sex determination (Wallace et al. 1999), and WW genotypes may generally be viable and fertile because $\mathrm{W}$ chromosomes do typically not seem to be decayed (Perrin 2009).

The potential of 'Trojan sex chromosomes' for boosting or reducing population growth still needs to be experimentally analysed. For now, the concept seems entirely theoretical, i.e. to the best of my knowledge no empirical test of this idea has been published so far. The same seems to be true for a genetic construct that has recently been suggested and modeled by Bax and Thresher (2009) and that would induce a shift in the sex ratio of fish population. The idea here is that if individuals with multiple copies of a genetically engineered aromatase inhibitor gene (D) are introduced into a problem population, all offspring of the D gene carrier that inherit the $\mathrm{D}$ gene would phenotypically develop into males regardless of the composition of their sex chromosome. Analogously to Gutierrez and Teem's (2006) original 'Trojan sex chromosomes' idea, the introduction of the $\mathrm{D}$ gene into a population could shift the sex ratio in future generations to a male bias that potentially reduces population growth.

\section{Conclusions}

It may often be possible to manipulate population sex ratios, for example by changing certain ecological or social factors that influence maternal decisions about family sex ratio, or by invasive techniques like, for example, introducing sex-reversed individuals into natural populations to boost or reduce population growth on the long run. If the aim of such manipulations is to support a small and endangered population, it is important to consider the possible dangers of the manipulation. If the sex ratio of a small population is found to be male-biased prior to the intervention, reducing this bias in future generations may generally be beneficial because this would be increasing the $\mathrm{N}_{\mathrm{e}}$ to $\mathrm{N}_{\mathrm{c}}$ ratio and thereby reducing the negative effects of small population size on population genetics. However, even if we deal with populations in which sex ratio directly determines population growth, any deviation from equal sex ratio towards a female-biased sex ratio reduces the $\mathrm{N}_{\mathrm{e}}$ to $\mathrm{N}_{\mathrm{c}}$ ratio, i.e. It may create a genetic bottleneck. On the long run, the likely negative effects of such a bottleneck would need to be compensated by the increased population growth that was achieved through the sex ratio manipulation (as, for example, modeled in Lenz et al. (2007)). Furthermore, by changing a population sex ratio we are changing demographic parameters that may significantly influence breeding systems, mate choice, sex-specific use of resources, or other life-history aspects (Emlen and Oring 1977, Andersson 1994). It may even be possible that we thereby risk losing culturally transmitted characteristics that could be linked to, for example, natural breeding systems. The potential costs and benefits of a sex ratio manipulation should therefore carefully optimized for any given situation, i.e. the optimal sex ratio manipulation is likely to differ from case to case.

In the case of small and declining populations, any kind of sex ratio manipulation is likely to fail if the underlying stressors and threats to the population are not appropriately dealt with. Moreover, many of the ideas discussed here are relatively new and lack empirical support. For example, the potential of manipulating female strategies in a given species is often unclear, and we need to learn more about the viability and the fertility of sex-reversed individuals in the wild to better estimate the potential of the 'Trojan Y chromosome' 
strategies to control or boost populations. However, it is clear that population sex ratio can be managed in attempting to reduce genetic bottlenecks and the effects of stochasticity in small or declining populations, and to control the spread of invasive species.

\section{Acknowledgments}

I thank Manuel Pompini and Tony Povilitis for comments on the draft manuscript, and the Swiss National Science Foundation for financial support.

\section{References}

Alho, J. S., C. Matsuba, and J. Merilä. 2010. Sex reversal and primary sex ratios in the common frogs (Rana temporaria). Molecular Ecology 19:1763-1773.

Allendorf, F. W. and G. Luikard. 2007. Conservation and the genetics of populations. Oxford University Press, Malden, MA, USA.

Andersson, M. 1994. Sexual selection. Princeton University Press, Princeton.

Aparicio, J. M. and P. J. Cordero. 2001. The effects of the minimum threshold condition for breeding on offspring sex-ratio adjustment in the lesser kestrel. Evolution 55:11881197.

Baroiller, J.-F., H. D'Cotta, and E. Saillant. 2009. Environmental effects on fish sex determination and differentiation. Sexual Development 3:118-135.

Bax, N. J. and R. E. Thresher. 2009. Ecological, behavioral, and geetics factors influecing the recombinant control of invasive pests. Evolutionary Applications 19:873-888.

Bernet, D., A. Liedtke, D. Bittner, R. I. L. Eggen, S. Kipfer, C. Küng, C. R. Largiadèr, M. J. F. Suter, T. Wahli, and H. Segner. 2008. Gonadal malformations in whitefish from Lake Thun: Defining the case and evaluating the role of EDCs. Chimia 62:383-388.

Bernet, D., T. Wahli, C. Küng, and H. Segner. 2004. Frequent and unexplained gonadal abnormalities in whitefish (central alpine Coregonus sp.) from an alpine oligotrophic lake in Switzerland. Diseases of Aquatic Organisms 61:137-148.

Bittner, D., D. Bernet, T. Wahli, H. Segner, C. Küng, and C. R. Largiadèr. 2009. How normal is abnormal? Discrimination between deformations and natural variation in gonad morphology of European whitefish Coregonus lavaretus. Journal of Fish Biology 74:1594-1614.

Bourbeau-Lemieux, A., M. Festa-Bianchet, J. M. Gaillard, and F. Pelletier. 2011. Predatordriven component Allee effects in a wild ungulate. Ecology Letters 14:358-363.

Bradbury, R. R. and J. K. Blakey. 1998. Diet, maternal condition, and offspring sex ratio the zebra finch, Poephila guttata. Proceedings of the Royal Society of London Series BBiological Sciences 265:895-899.

Brykov, V. A., A. D. Kukhlevsky, E. A. Shevlyakov, N. M. Kinas, and L. O. Zavarina. 2008. Sex ratio control in pink salmon (Oncorhynchus gorbuscha and chum salmon (O-keta) populations: The possible causes and mechanisms of changes in the sex ratio. Russian Journal of Genetics 44:786-792.

Bull, J. J. 1983. Evolution of sex determining mechanisms. Benjamin/Cummings Publishing Company, Inc, Menlo Park, CA.

Bunnefeld, N., D. Baines, D. Newborn, and E. J. Milner-Gulland. 2009. Factors affecting unintentional harvesting selectivity in a monomorphic species. Journal of Animal Ecology 78:485-492. 
Burley, N. 1982. Reputed band attractiveness and sex manipulation in zebra finches. Science 215:423-424.

Cassinello, J. and M. Gomendio. 1996. Adaptive variation in litter size and sex ratio at birth in a sexually dimorphic ungulate. Proceedings of the Royal Society of London Series B-Biological Sciences 263:1461-1466.

Charnov, E. L. 1982. The theory of sex allocation. Princeton University Press, Princeton.

Chowen, T. R. and J. J. Nagler. 2004. Temporal and spatial occurrence of female Chinook salmon carrying a male-specific genetic marker in the Columbia River watershed. Environmental Biology of Fishes 69:427-432.

Chowen, T. R. and J. J. Nagler. 2005. Lack of sex specificity for growth hormone pseudogene in fall-run Chinook salmon from the Columbia River. Transactions of the American Fisheries Society 134:279-282.

Clout, M. N., G. P. Elliott, and B. C. Robertson. 2002. Effects of supplementary feeding on the offspring sex ratio of kakapo: a dilemma for the conservation of a polygynous parrot. Biological Conservation 107:13-18.

Cnaani, A. and B. Levavi-Sivan. 2009. Sexual development in fish, practical applications for aquaculture. Sexual Development 3:164-175.

Conover, D. O. and D. A. Van Voorhees. 1990. Evolution of a balanced sex ratio by frequency-dependent selection in a fish. Science 250:1556-1558.

Conover, D. O., D. A. Vanvoorhees, and A. Ehtisham. 1992. Sex-ratio selection and the evolution of environmental sex determination in laboratory populations of Menidia menidia. Evolution 46:1722-1730.

Cotton, S. and C. Wedekind. 2007a. Control of introduced species using Trojan sex chromosomes. Trends in Ecology \& Evolution 22:441-443.

Cotton, S. and C. Wedekind. 2007b. Introduction of Trojan sex chromosomes to boost population growth. Journal of Theoretical Biology 249:153-161.

Cotton, S. and C. Wedekind. 2009. Population consequences of environmental sex reversal. Conservation Biology 23:196-206.

Courchamp, F., T. Clutton-Brock, and B. Grenfell. 1999. Inverse density dependence and the Allee effect. Trends in Ecology \& Evolution 14:405-410.

Devlin, R. H. and Y. Nagahama. 2002. Sex determination and sex differentiation in fish: an overview of genetic, physiological, and environmental influences. Aquaculture 208:191-364.

Dobson, A. P. and A. M. Lyles. 2000. Black-footed ferret recovery. Science 288:985-988.

Ellegren, H., L. Gustafsson, and B. C. Sheldon. 1996. Sex ratio adjustment in relation to paternal attractiveness in a wild bird population. Proceedings of the National Academy of Sciences of the United States of America 93:11723-11728.

Emlen, S. T. and L. W. Oring. 1977. Ecology, sexual selection, and the evolution of mating systems. Science 197:215-223.

Felsenstein, J. 1974. The evolutionary advantage of recombination. Genetics 78:737-756.

Fisher, R. A. 1930. The genetical theory of natural selection. Clarendon Press, Oxford.

Frankham, R., J. D. Ballou, and D. A. Briscoe. 2002. Introduction to conservation genetics. Cambridge University Press, Cambridge.

Gibbons, E. F., B. S. Durrant, and J. Demarest, editors. 1995. Conservation of endangered species in captivity. State University of New York Press, Albany.

Girondot, M., H. Fouillet, and C. Pieau. 1998. Feminizing turtle embryos as a conservation tool. Conservation Biology 12:353-362. 
Gomendio, M., T. H. Cluttonbrock, S. D. Albon, F. E. Guinness, and M. J. Simpson. 1990. Mammalian sex-ratios and variation in costs of rearing sons and daughters. Nature 343:261-263.

Grahn, M., A. Langesfors, and T. von Schantz. 1998. The importance of mate choice in improving viability in captive populations. Pages 341-363 in T. M. Caro, editor. Behavioral Ecology and Conservation Biology. Oxford University Press, Oxford.

Gutierrez, A., J. DeLaFuente, S. Fuentes, A. Payas, C. Ugarte, and B. Pintado. 1995. Influence of biopsy sexing and in vitro culture on losses of female mouse and bovine embryos. Animal Biotechnology 6:101-109.

Gutierrez, J. B. and J. L. Teem. 2006. A model describing the effect of sex-reversed YY fish in an established wild population: the use of a Trojan Y chromosome to cause extinction of an introduced exotic species. Journal of Theoretical Biology 241:333-341.

Hanfling, B., F. Edwards, and F. Gherardi. 2011. Invasive alien Crustacea: dispersal, establishment, impact and control. Biocontrol 56:573-595.

Harries, J. E., D. A. Sheahan, S. Jobling, P. Matthiessen, M. Neall, J. P. Sumpter, T. Taylor, and N. Zaman. 1997. Estrogenic activity in five United Kingdom rivers detected by measurement of vitellogenesis in caged male trout. Environmental Toxicology and Chemistry 16:534-542.

Hartl, D. L. 1988. A primer of population genetics, second edition. Sinauer Associates, Inc., Sunderland, Massachusetts.

Heath, D. D., J. W. Heath, C. A. Bryden, R. M. Johnson, and C. W. Fox. 2003. Rapid evolution of egg size in captive salmon. Science 299:1738-1740.

Hedrick, P. W. 2005. Genetics of populations, 3rd edition. Jones \& Bartlett Publishers, Sudbury, MA, USA.

Hillis, D. M. and D. M. Green. 1990. Evolutionary changes of heterogametic sex in the phylogenetic history of amphibians. Journal of Evolutionary Biology 3:49-64.

Hurley, M. A., P. Matthiessen, and A. D. Pickering. 2004. A model for environmental sex reversal in fish. Journal of Theoretical Biology 227:159-165.

Jacob, A., G. Evanno, B. A. von Siebenthal, C. Grossen, and C. Wedekind. 2010. Effects of different mating scenarios on embryo viability in brown trout. Molecular Ecology 19:5296-5307.

Janzen, F. J. 1994. Climate change and temperature-dependent sex determination in reptiles. Proceedings of the National Academy of Sciences of the United States of America 91:7487-7490.

Janzen, F. J., J. W. Gibbons, J. L. Greene, J. B. Iverson, and J. K. Tucker. 2006. Climate change and temporal variation in nesting biology of North American turtles. Integrative and Comparative Biology 46:E69-E69.

Jobling, S. and C. R. Tyler. 2003. Endocrine disruption in wild freshwater fish. Pure and Applied Chemistry 75:2219-2234.

Jobling, S., R. Williams, A. Johnson, A. Taylor, M. Gross-Sorokin, M. Nolan, C. R. Tyler, R. van Aerle, E. Santos, and G. Brighty. 2006. Predicted exposures to steroid estrogens in UK rivers correlate with widespread sexual disruption in wild fish populations. Environmental Health Perspectives 114:32-39.

Kamel, S. J. and N. Mrosovsky. 2006. Deforestation: risk of sex ratio distortion in hawsbill sea turtles. Ecological Applications 16:923-931.

Kanaiwa, M. and Y. Harada. 2002. Genetic risk involved in stock enhancement of fish having environmental sex determination. Population Ecology 44:7-15. 
Kapuscinski, A. R., K. R. Hayes, and L. Sifa, editors. 2007. Environmental risk assessment of genetically modified organisms, volume 3: transgenic fish in developing countries. CAB International Publishing, Wallingford, UK.

King, W. A., L. Picard, D. Bousquet, and A. K. Goff. 1992. Sex-dependent loss of bisected bovine morulae after culture and freezing. Journal of Reproduction and Fertility 96:453-459.

Kolar, C. S. and D. M. Lodge. 2002. Ecological predictions and risk assessment for alien fishes in North America. Science 298:1233-1236.

Krackow, S. 1995. The developmental asynchrony hypothesis for sex-ratio manipulation. Journal of Theoretical Biology 176:273-280.

Lande, R. 1998. Anthropogenic, ecological and genetic factors in extinction. Pages 29-51 in G. M. Mace, A. Balmford, and J. R. Ginsberg, editors. Conservation in a changing world. Cambridge University Press, Cambridge.

Lanza, R. P., B. L. Dresser, and P. Damiani. 2000. Cloning Noah's ark. Scientific American 283:84-89.

Larsson, D. G., H. Hallman, and L. Förlin. 2000. More male fish embryos near a pulp mill. Environmental Toxicology and Chemistry 19:2911-2917.

Lenz, T. L., A. Jacob, and C. Wedekind. 2007. Manipulating sex ratio to increase population growth: the example of the Lesser Kestrel. Animal Conservation 10:236-244.

Louda, S. M. and P. Stiling. 2004. The double-edged sword of biological control in conservation and restoration. Conservation Biology 18:50-53.

Magerhans, A., A. Müller-Belecke, and G. Hörstgen-Schwark. 2009. Effect of rearing temperatures post hatching on sex ratios of rainbow trout (Oncorhynchus mykiss) populations. Aquaculture 294:25-29.

Marealle, W. N., F. Fossoy, T. Holmern, B. G. Stokke, and E. Roskaft. 2010. Does illegal hunting skew Serengeti wildlife sex ratios? Wildlife Biology 16:419-429.

Milinski, M. and T. C. M. Bakker. 1992. Costs influence sequential mate choice in sticklebacks, Gasterosteus aculeatus. Proceedings of the Royal Society of London Series B-Biological Sciences 250:229-233.

Muir, W. M. and R. D. Howard. 2004. Characterization of environmental risk of genetically engineered (GE) organisms and their potential to control exotic invasive species. Aquatic Sciences 66:414-420.

Muller, H. J. 1932. Some genetic aspects of sex. American Naturalist 66:118-138.

Myers, J. H., D. Simberloff, A. M. Kuris, and J. R. Carey. 2000. Eradication revisited: dealing with exotic species. Trends in Ecology \& Evolution 15:316-320.

Nagler, J. J., J. Bouma, G. H. Thorgaard, and D. D. Dauble. 2001. High incidence of a malespecific genetic marker in phenotypic female Chinook salmon from the Columbia River. Environmental Health Perspectives 109:67-69.

Nomura, T. 2002. Effective size of populations with unequal sex ratio and variation in mating success. Journal of Animal Breeding and Genetics 119:297-310.

Olsen, J. B., S. J. Miller, K. Harper, J. J. Nagler, and J. K. Wenburg. 2006. Contrasting sex ratios in juvenile and adult chinook salmon Oncorhynchus tshawytscha (Walbaum) from south-west Alaska: sex reversal or differential survival? Journal of Fish Biology 69:140-144.

Ospina-Alvarez, N. and F. Piferrer. 2008. Temperature-dependent sex determination in fish revisited: prevalence, a single sex ratio response pattern, and possible effects of climate change. PLoS ONE 3:e2837. 
Palmer, A. R. 2000. Quasi-replication and the contract of error: lessons from sex ratios, heritabilities and fluctuating asymmetry. Annual Review of Ecology and Systematics 31:441-480.

Pandian, T. J. and S. G. Sheela. 1995. Hormonal induction of sex reversal in fish. Aquaculture 138:1-22.

Parks, L. G., C. S. Lambright, E. F. Orlando, L. J. Guillette, G. T. Ankley, and L. E. Gray. 2001. Masculinization of female Mosquitofish in a kraft mill effluent-contaminated Fenholloway River water is associated with androgen receptor agonist activity. Toxicological Sciences 62:257-267.

Penáz, M., Z. Svbodová, V. Barus, M. Prokes, and J. Drastichova. 2005. Endocrine disruption in a barbel, Barbus barbus population from the River Jihlava. Journal of Applied Ichthyology 21:420-428.

Perret, M. 1996. Manipulation of sex ratio at birth by urinary cues in a prosimian primate. Behavioral Ecology and Sociobiology 38:259-266.

Perrin, N. 2009. Sex reversal: a fountain of youth for sex chromosomes? Evolution 63:30433049.

Piferrer, F. 2001. Endocrine sex control strategies for the feminization of teleost fish. Aquaculture 197:229-281.

Poulin, R., R. A. Paterson, C. R. Townsend, D. M. Tompkins, and D. W. Kelly. 2011. Biological invasions and the dynamics of endemic diseases in freshwater ecosystems. Freshwater Biology 56:676-688.

Rankin, D. J. and H. Kokko. 2007. Do males matter? The role of males in population dynamics. Oikos 116:335-348.

Real, L. A. 1991. Search theory and mate choice .2. mutual interaction, assortative mating, and equilibrium variation in male and female fitness. American Naturalist 138:901-917.

Rice, W. R., S. Gavrilets, and U. Friberg. 2008. Sexually antagonistic "zygotic drive" of the sex chromosomes. Plos Genetics 4.

Robertson, B. C., G. P. Elliott, D. K. Eason, M. N. Clout, and N. J. Gemmell. 2006. Sex allocation theory aids species conservation. Biology Letters 2:229-231.

Ryman, N. and L. Laikre. 1991. Effects of supportive breeding on the genetically effective population-size. Conservation Biology 5:325-329.

Saino, N., H. Ellegren, and A. P. Møller. 1999. No evidence for adjustment of sex allocation in relation to paternal ornamentation and paternity in barn swallows. Molecular Ecology 8:399-406.

Schliekelman, P., S. Ellner, and F. Gould. 2005. Pest control by genetic manipulation of sex ratio. Journal of Economic Entomology 98:18-34.

Schliekelman, P. and F. Gould. 2000. Pest control by the release of insects carrying a femalekilling allele on multiple loci. Journal of Economic Entomology 93:1566-1579.

Solari, A. J. 1994. Sex chromosomes and sex determination in vertebrates. CRC Press, Boca Raton, Florida.

Stelkens, R. B. and C. Wedekind. 2010. Environmental sex reversal, Trojan sex genes, and sex ratio adjustment: conditions and population consequences. Molecular Ecology 19:627-646.

Stephens, P. A. and W. J. Sutherland. 1999. Consequences of the Allee effect for behaviour, ecology and conservation. Trends in Ecology \& Evolution 14:401-405. 
Sumpter, J. P. and S. Jobling. 1995. Vitellogenesis as a biomarker for estrogenic contamination of the aquatic environment. Environmental Health Perspectives 103:173-178.

Tella, J. L. 2001. Sex-ratio theory in conservation biology. Trends in Ecology \& Evolution 16:76-77.

Thailayil, J., K. Magnusson, H. C. J. Godfray, A. Crisanti, and F. Catteruccia. 2011. Spermless males elicit large-scale female responses to mating in the malaria mosquito Anopheles gambiae. Proceedings of the National Academy of Sciences of the United States of America 108:13677-13681.

Tinbergen, N. 1963. On aims and methods of ethology. Zeitschrift fur Tierpsychologie 20:410-433.

Trivers, R. L. and D. E. Willard. 1973. Natural selection of parental ability to vary the sex ratio of offspring. Science 179:90-91.

Tryjanowski, P., T. H. Sparks, R. Kamieniarz, and M. Panek. 2009. The relationship between hunting methods and sex, age and body weight in a non-trophy animal, the red fox. Wildlife Research 36:106-109.

Valenzuela, N. and V. A. Lance, editors. 2004. Temperature-dependent sex determination in vertebrates. Smithsonian Institution, Washington.

Vos, J. G., E. Dybing, H. A. Greim, O. Ladefoged, C. Lambre, J. V. Tarazona, I. Brandt, and A. D. Vethaak. 2000. Health effects of endocrine-disrupting chemicals on wildlife, with special reference to the European situation. Critical Reviews in Toxicology 30:71-133.

Wallace, H., G. M. I. Badawy, and B. M. N. Wallace. 1999. Amphibian sex determination and sex reversal. CMLS Cellular and Molecular Life Sciences 55:901-909.

Wedekind, C. 2002a. Manipulating sex ratios for conservation: short-term risks and longterm benefits. Animal Conservation 5:13-20.

Wedekind, C. 2002b. Sexual selection and life-history decisions: implications for supportive breeding and the management of captive populations. Conservation Biology 16:1204-1211.

Wedekind, C. 2010. Searching for sex-reversals to explain population demography and the evolution of sex chromosomes. Molecular Ecology 19:1760-1762.

Wedekind, C. and C. Küng. 2010. Shift of spawning season and effects of climate warming on developmental stages of a grayling (Salmonidae). Conservation Biology 24:1418-1423.

Wedekind, C., R. Müller, and H. Spicher. 2001. Potential genetic benefits of mate selection in whitefish. Journal of Evolutionary Biology 14:980-986.

Wedekind, C., G. Rudolfsen, A. Jacob, D. Urbach, and R. Müller. 2007. The genetic consequences of hatchery-induced sperm competition in a salmonid. Biological Conservation 137:180-188.

Westerdahl, H., S. Bensch, B. Hansson, D. Hasselquist, and T. VonSchantz. 1997. Sex ratio variation among broods of great reed warblers Acrocephalus arundinaceus. Molecular Ecology 6:543-548.

Williamson, K. S., R. Phillips, and B. May. 2008. Characterization of a chromosomal rearrangement responsible for producing "Apparent" XY-female fall-run Chinook salmon in California. Journal of Heredity 99:483-490.

Young, A. G. and G. M. Clarke, editors. 2000. Genetics, demography and viability of fragmented populations. Cambridge University Press, Cambridge UK. 


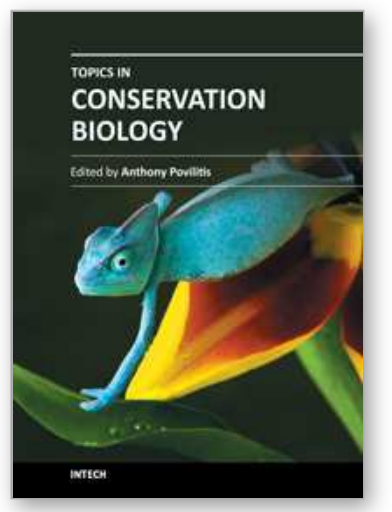

\author{
Topics in Conservation Biology \\ Edited by Dr. Tony Povilitis
}

ISBN 978-953-51-0540-4

Hard cover, 110 pages

Publisher InTech

Published online 02, May, 2012

Published in print edition May, 2012

Conservation biology is called a "crisis discipline." In a world undergoing rapid change, this science informs us about research, technologies, management practices, and policies that can help protect the earth's naturallyoccurring biological diversity. The six chapters of this book provide insightful analysis on managing protected areas (Middle East), conserving biochemical and genetic diversity of carob tree (Tunisia) and wild pear (Japan), determining the health status of Amazon manatee, manipulating sex ratios to benefit wildlife, and narrowing the gap between religion and conservation. The authors approach threats to biological diversity from varied angles, reflecting the interdisciplinary nature of the field. This book offers room for reflection on the definition and utility of the word 'natural' on a planet now overwhelmingly dominated by people.

\title{
How to reference
}

In order to correctly reference this scholarly work, feel free to copy and paste the following:

Claus Wedekind (2012). Managing Population Sex Ratios in Conservation Practice: How and Why?, Topics in Conservation Biology, Dr. Tony Povilitis (Ed.), ISBN: 978-953-51-0540-4, InTech, Available from:

http://www.intechopen.com/books/topics-in-conservation-biology/managing-population-sex-ratio-why-and-how

\section{INTECH}

open science | open minds

\section{InTech Europe}

University Campus STeP Ri

Slavka Krautzeka 83/A

51000 Rijeka, Croatia

Phone: +385 (51) 770447

Fax: +385 (51) 686166

www.intechopen.com

\section{InTech China}

Unit 405, Office Block, Hotel Equatorial Shanghai

No.65, Yan An Road (West), Shanghai, 200040, China

中国上海市延安西路65号上海国际贵都大饭店办公楼405单元

Phone: +86-21-62489820

Fax: +86-21-62489821 
(C) 2012 The Author(s). Licensee IntechOpen. This is an open access article distributed under the terms of the Creative Commons Attribution 3.0 License, which permits unrestricted use, distribution, and reproduction in any medium, provided the original work is properly cited. 